IZA DP No. 6119

Sizing It Up:

Labor Migration Lessons of the EU Enlargement to 27

Amelie F. Constant

November 2011 


\title{
Sizing It Up: \\ Labor Migration Lessons of the EU Enlargement to 27
}

\author{
Amelie F. Constant \\ DIWDC, George Washington University \\ and IZA
}

Discussion Paper No. 6119

November 2011

\author{
IZA \\ P.O. Box 7240 \\ 53072 Bonn \\ Germany \\ Phone: +49-228-3894-0 \\ Fax: +49-228-3894-180 \\ E-mail: iza@iza.org
}

\begin{abstract}
Any opinions expressed here are those of the author(s) and not those of IZA. Research published in this series may include views on policy, but the institute itself takes no institutional policy positions.

The Institute for the Study of Labor (IZA) in Bonn is a local and virtual international research center and a place of communication between science, politics and business. IZA is an independent nonprofit organization supported by Deutsche Post Foundation. The center is associated with the University of Bonn and offers a stimulating research environment through its international network, workshops and conferences, data service, project support, research visits and doctoral program. IZA engages in (i) original and internationally competitive research in all fields of labor economics, (ii) development of policy concepts, and (iii) dissemination of research results and concepts to the interested public.
\end{abstract}

IZA Discussion Papers often represent preliminary work and are circulated to encourage discussion. Citation of such a paper should account for its provisional character. A revised version may be available directly from the author. 
IZA Discussion Paper No. 6119

November 2011

\section{ABSTRACT \\ Sizing It Up: \\ Labor Migration Lessons of the EU Enlargement to 27}

While economists were pointing out the advantages of the EU enlargement, politicians and policymakers were raising grave concerns about the significant political and economic differences between the newcomer states (EU12) and the "old Europe" of EU15. The major point of apprehension was related to the labor markets. Visceral fear rendered more than one in two Europeans to believe that the EU enlargement contributed to job losses in their own country. Some EU15 member states opted for transitional arrangements and did not allow labor mobility from the EU12. This chapter reviews the achievements of the first five years of the EU27 and assesses and evaluates the effectiveness of the enforced policies while it identifies winner and losers. Overall, the EU enlargement did not produce any negative effects or disruptions in the labor markets of the Member States. All three agents, the migrants, the receiving countries, and the sending countries gained from labor mobility. The EU15 countries with closed door policy lost in high-skilled labor and their labor markets experienced a delayed adjustment that overlapped with the global crisis and exacerbated negativity. As self-employed labor was not under the same mobility Act, the self-employed were able to move to the country they were needed and open successful businesses. The global crisis tainted the rosy results of the enlargement and left the EU27 vulnerable to shocks.

JEL Classification: J6, J3, F22, F24

Keywords: labor mobility, labor policy, EU enlargement, wages, international migration, remittances

Corresponding author:

Amelie F. Constant

DIWDC

1800 K Street, NW

Suite 716

Washington, DC 20006

USA

E-mail: constant@diwdc.org 


\section{Introduction}

On May 1, 2009, the European Union (EU) ${ }^{1}$ celebrated the fifth anniversary of its historic enlargement. In May 2004, Cyprus, the Czech Republic, Estonia, Hungary, Latvia, Lithuania, Malta, Poland, Slovakia and Slovenia joined the 15 other countries already in the EU; Bulgaria and Romania joined in January 2007. It was an amazing moment for the visionaries who had been pushing for a united Europe with free mobility of goods, services and labor.

Economists know well that eliminating barriers to trade, to capital flows and to migration brings about tremendous gains. The geographic mobility of workers, in particular, can act as the equilibrating factor between demand and supply in labor markets, while it also contributes to better skill matches; positive externalities usually outweigh the negative ones. Calculated at the 2005 wage and productivity gap between Western and Eastern Europe, Boeri and Bruecker (2005) showed that a 3\% Eastern migration to the West could increase total EU Gross Domestic Product (GDP) by up to $0.5 \%$. D’Auria et al. (2008) found that following the 2004 EU enlargement GDP increased and there was a small positive effect on employment, albeit GDP per capita decreased. Retrospectively, the European Commission (2009) asserted that between 2004 and 2007 there were 12.2 million jobs created in the EU27, and that in 2007 the employment rate reached 65.4\%. Looking at existing estimates, Clemens (2011) suggested that even small reductions in the barriers to labor mobility could bring enormous gains, often in the range between $50 \%$ and $150 \%$ of world GDP.

Yet, politicians and policymakers in the EU15 raised grave concerns about the significant political and economic differences between the newcomer states (EU12) and the "old Europe" of EU15. Additional confusion in the media portrayed enlargement as encroachment and unfair competition with economic, social, cultural and political consequences. As labor mobility became the one and only focal point, a large number of EU15 citizens expressed fear and suspicion in anticipation of a future inundation by the EU10 citizens. Subsequently, some EU15 countries refused free labor mobility to the newcomers.

\footnotetext{
${ }^{1}$ EU indicates the EU of all 27 member states (EU27). EU15 or Old Member States (OMS) are Austria, Belgium, Denmark, Finland, France, Germany, Greece, Ireland, Italy, Luxembourg, the Netherlands, Portugal, Spain, Sweden and the United Kingdom. EU10 refers to member states that joined EU on May 1, 2004. They were Cyprus, the Czech Republic, Estonia, Hungary, Latvia, Lithuania, Malta, Poland, Slovakia and Slovenia. EU8 refers to EU10 member states but without Cyprus and Malta. EU12 or New Member States (NMS) refers to EU10 plus Bulgaria and Romania that joined the EU on January 1, 2007. EU25 refers to the 25 member states that were united before January 1, 2007.
} 
Germany and Austria, for example, fearing that thousands of Eastern Europeans would inundate their labor markets consequently creating unemployment and lower wages for natives, imposed a stringent transition period of a maximum of seven years. Similarly, Greece, Hungary, Portugal and Spain kept their doors closed for the EU2 until January 2009.

It important to note here that we refer to free mobility of salaried workers (as it is provided in Article 39). The EU law, explicitly distinguishes salaried workers from the self-employed, who are protected under Article 43. Accordingly, the transitional arrangements can only apply to salaried workers. EU workers and their families are protected under the EU law against discrimination due to their nationality vis-à-vis employment, public housing, tax advantages and social advantages. Lastly, a Member State should always give preference to workers from the NMS than workers from non-EU countries (European Commission, 2009).

As it is always true in economics, whenever a shock occurs (either because of an unexpected act, a natural experiment or a government intervention), it creates a group of gainers and a group of losers. The economist's task is then to identify these groups, and evaluate the gains and losses at the aggregate level. A possible outcome is a Pareto improvement, that is, given an initial distribution of goods among individuals, moving to a different distribution that makes at least one individual better off without making any other individual worse off is called a Pareto improvement. ${ }^{2}$

The purpose of this chapter is to take stock of the EU27 current state of affairs, to assess the impact of the 2004 historic natural experiment on free mobility, and to examine and judge the effectiveness of the enacted policies and their ramifications on the sending and the receiving countries. Special emphasis will be paid on the functioning of the labor markets, human capital and the movement of people. Our evaluation and drawing of lessons from this experiment would be tainted if we would not account for the 2008 global economic and financial crises that affected almost all EU27 members one way or another. The impact of the economic crisis on migration flows in Europe and implications for public policy in the enlarged EU of 27 will be discussed.

\footnotetext{
${ }^{2}$ This notion is about improving efficiency and does not imply anything about equity and ethics.
} 


\section{European Labor Markets, Human Capital Immobility, and the Digital Age}

Right at the beginning of the 21st century, in March 2000, the European Council set up the "Lisbon Agenda" or "Lisbon Strategy." The Lisbon Agenda was meant to be the new directive for the decade that could address globalization challenges, combat social exclusion, render the EU the most dynamic knowledge-based economy in the world with full employment for all, while ensuring that economic growth be decoupled. In 2001, the Stockholm European Council set intermediate targets for deliverables and required a mid-term review in 2005. Accordingly, all member states should adopt national reform programs with priority on lasting economic growth and the creation of more and better jobs; many member states started implementing Active Labor Market Policies (ALMP). The Stockholm Council also endorsed concrete objectives about education and training. Facilitating universal access to education, and opening up education and training systems to the wider world were top priorities. The Copenhagen Declaration in November 2002 explicitly stated that "strategies for lifelong learning and mobility are essential to promote employability, active citizenship, social inclusion and personal development." The aim was to increase voluntary cooperation in vocational education and training, while promoting mutual trust, transparency and recognition of competences and qualifications.

While the free mobility of people in a united Europe is one of the four fundamental freedoms of the EU, there has been virtually no labor mobility among member states. Oddly enough, the more people are free to move and work within the EU, the less they actually move. The percent of EU15 nationals in other EU15 states has been low and stable over time. On average, between 2000 and 2005, workers’ mobility within EU15 amounted to only 1\% each year (Bonin et al., 2008). This Eurosklerosis phenomenon is difficult to be explained by economic theory, which posits that labor mobility contributes to an optimal allocation of economic resources, generates higher output by reaching a higher Production Possibilities Frontier (PPF), increases wellbeing, and ensures a quick adjustment of labor market inefficiencies. The exception to the European labor immobility was the Scandinavian countries that instituted "flexicurity," a policy model combining labor market flexibility and security for workers of being in employment, along with ALMP.

Traditionally, the majority of foreign residents in the EU15 have been nationals from non-EU countries. In the new EU27, the treaties stated that an EU member state must prefer workers from the New Member States (NMS) over workers from non-EU countries. However, after the NMS joined EU to 
form the EU27 the majority of immigrants were still from non-EU countries; the share of EU12 migrants in the EU15 was relatively low. The average mobility rate from the NMS to the EU15 countries was about 0.2\% (Bonin et al., 2008). Moreover, the share of non-EU27 nationals in the EU15 increased, especially in Greece, Spain, Portugal, Denmark and the United Kingdom (UK).

Reasons explaining the low labor mobility within the EU are: the accelerating ageing of the work population, the rise of female employment in dual income households, the continuous rise in homeownership, lack of innovation dynamics, decline in the number of available new jobs and the changing of traditional jobs to digital ones. Institutional barriers such as administrative delay and variation in the level of payments of social security benefits, limited transferability of (supplementary) pensions, legal and administrative problems concerning the different taxation systems, differences in health care systems, and limited portability and recognition of education degrees and qualifications are often cited as important hurdles to labor mobility within the EU15. Lastly, language and cultural differences can also constitute barriers to labor mobility within the EU.

The 2005 mid-term review found the Lisbon Agenda unsatisfactory. While the Commission introduced additional measures in December 2007 such as the Job Mobility Action Plan, the 2010 evaluation revealed that the Lisbon Agenda targets were not met (European Commission, 2010). In March 2010, the Commission set up a new roadmap, "Europe 2020." The main objectives of Europe 2010 were to increase employment rates and invest in R\&D mainly by boosting private sector investment and by developing a new innovation indicator. Reducing drop-out rates and increasing the schooling level of the 30 to 34 years old as well as lifting 20 million people out of poverty were also essential goals.

In June 2008, the EU adopted the Small Business Act (SBA) with the vision to support entrepreneurship, cut on red tape when starting up a business, reduce VAT rates, and exempt microenterprises from accounting rules (European Commission, 2009).

The world is now digital. Most of the jobs that exist today may not exist tomorrow and many other digital jobs inconceivable today will be mainstream tomorrow. Promoting lifelong learning and active ageing as well as mobilizing the potential of immigrants is the new pursuit of all in EU27. Producing the "right" human capital that withstands the unpredictable genesis of digital jobs and feeds into innovation is the way to have a strong knowledge-based European economy. In fact, as Europe is 
exiting the economic crisis of 2008 and as it is grappling with the Eurozone crisis and the sovereign debt crisis, jobs become all the more relevant.

\section{The EU Enlargement Scare}

Around 2003, right before the effective enlargement, Europe was confronted by looming threats of ageing populations and declining fertility rates; it was also grappling with economic problems, unemployment and integration issues of its immigrant populations. Because barriers to trading goods and services, and to foreign direct investments had been abolished before the EU enlargement, the most common pre-enlargement fears were mass migration (including illegal immigration), "welfare tourism”3 and domestic labor displacement. These fears resulted in resistance by many EU15 receiving countries to open up their labor markets. To address concerns and fears about potential labor market disruptions, most OMS introduced transitional arrangements based on the ' $2+3+2$ ' formula. This transitional period of a maximum of seven years is divided into three phases in which different conditions apply during each phase (European Commission, 2009). All transitional arrangements for the EU10 should end by April 30, 2011; for the EU2 states the transition period should end on December 31, 2013.

Ireland, the UK and Sweden were the first members of EU15 to open up and uphold free labor mobility. Naturally, they became a popular destination for the NMS migrants. Table 1 documents the current transitional provisions for the EU2 NMS (Bulgaria and Romania) and EU25. Germany can serve as a valuable paradigm of a "closed" economy within the EU27. While Germany has been imposing stringent restrictions on labor migrants from the EU8 countries, it was at the same time allowing a preferred entrance to the very high-skilled workers. Another exception referred to selfemployment. EU's Acts of ascension explicitly excluded the self-employed, who were not to be subject to any transitional arrangements. Keeping with the spirit of the Lisbon Agenda to promote a "more entrepreneurial culture and a supportive environment for small and medium size enterprises” Germany has been encouraging and rewarding the self-employed migrants who would open up their business in

\footnotetext{
${ }^{3}$ Welfare tourism indicates the phenomenon of tourists abusing the system of residency and claiming welfare benefits from a member state.
} 
Germany. ${ }^{4}$ This was the country's effort to use migration as a potential economic boon and to abide by the EU's laws. The self-employment policy, however, included some employment restrictions on foreign born business owners to keep them from hiring workers who were of the same nationality (Constant et al., 2010). Table 2 shows that Germany would have actually experienced a net loss of migration without migration from the EU8 and the enacted exceptions.

\section{$<<<$ Table 1 about here $>>>$}

\section{$<<<$ Table 2 about here $>>>$}

The relevant question here is how afraid were the EU15 citizens from the EU27 enlargement? And, were their fears justified? The 2009 European Commission Eurobarometer offers an alarming actuality; more than one in two Europeans in the EU27 appear convinced that the EU enlargement contributed to job losses in their own country. Figure 1 presents the 'agrees' and 'disagrees' to the job loss inquiry by EU member states. Among the EU15, Greeks lead the way with 80\% of them agreeing that the EU enlargement has contributed to job losses in Greece. Next, are the Portuguese with 72\% followed by $59 \%$ of Germans and French. At the other end of the spectrum are the Scandinavians with 58\% of Swedes and Finns disagreeing that the EU enlargement contributed to job losses in their countries. The Dutch join the group with 58\% as well, while 54\% of Danes and Luxembourgers also disagreed that the EU enlargement has contributed to job losses in their countries.

\section{$<<<$ Figure 1 about here $>>>$}

Figure 1 also presents the 'agrees' and 'disagrees' among the NMS nationals. Hungarians lead the way with $75 \%$ of them agreeing that the EU enlargement took jobs away from them. They are followed by Cypriots (73\%) and Romanians and Latvians with 70\%. Maltese on the other hand, do not agree (51\%) that the EU enlargement contributed to job losses in Malta.

Figure 2 presents the answers to the same question by sex, age, education, urbanization and occupation. The majority of European women (58\%) agree that the EU enlargement has contributed to job losses.

\footnotetext{
${ }^{4}$ For immigrants from non-EU countries, §21 of the Residence Act of 2005 effectively regulates the entry and economic activity of the self-employed immigrants. According to the Act, self-employed migrants who could invest at least 250,000 Euros and create a minimum of five jobs could receive a residence permit. Until 2007, the required minimum investment for self-employment was one million Euros or a minimum of 10 new jobs created through this venture.
} 
In this thesis, they are joined by an overwhelming majority of people above 55 years of age (61\%), people with lower education levels (64\% of those with only primary schooling), people in rural areas (58\%), and manual workers (67\%).

\section{$<<<$ Figure 2 about here $>>>$}

Scientific empirical evidence does not support these fears. The Kahanec and Zimmermann (2009) book, devoted to the EU post-enlargement migration, shows no evidence of displacement of native workers, of lowering wages, or of dependency on welfare due to the EU enlargement. The 2009 report of the European Commission stated that between 2004 and 2007 both the OMS and the NMS experienced an increase in employment. While in the OMS employment rates increased by 2.2 percentage points to reach $67 \%$ in 2007, in the MNS employment rates increased by $7 \%$ in five years, that is, from $55.9 \%$ in 2004 to 59.8\% in 2009. The same report concluded that there have not been any serious disturbances in the labor markets from the EU enlargement to 27, meaning there were no negative effects from the free mobility of NMS labor to the OMS. This is because the benefits from opening the labor markets are larger than any costs both at the aggregate and the regional level.

\section{Fundamentals of Labor Migration: Benefits for All in EU?}

In general, labor migration benefits all three actors: the migrants themselves, the economies of the host or receiving and home or sending countries. Unfettered movement benefits the migrants themselves because they move to areas where their skills are demanded and rewarded. In doing so, they improve the allocative efficiency of the labor markets. As migrants become better off, they can remit back to their home countries. Remittances are not only a substantial source of income in the home countries, but they can also drive economic growth when recipients can invest in education and start up capitalintensive businesses. In general, the positive impact of remittances in the home country increases with the income differential between home and host areas. While remittances are less important in the intraEU15 mobility, they may play an important positive role in the economic development of the NMS. In addition, while brain drain may be a concern in the sending countries (if the "brainy" people emigrate), their brain circulation can facilitate international trade, transfer of technologies and knowledge, and eliminate bottlenecks to economic development. 
However, any movement can have redistributive effects. As predicted by microeconomic theory, it all impinges upon the substitutability and complementarity of the factors of production. Unskilled migrant labor is usually considered a substitute to physical capital. It is also complementary to skilled native labor, thus resulting in a beneficial outcome. Unskilled workers provide a low sturdy bottom for the skilled workers who are freed to move upwards. At the same time, unskilled immigrant workers create serious competition to unskilled native workers. Usually, this implies unemployment for the unskilled natives. In contrast, skilled migrant labor produces a different set of results. Skilled migrant labor does not necessarily adversely affect skilled native workers. At this level of sophistication and specialization skilled migrant labor and skilled native labor may be complements in the production process helping each other to upward mobility. Kahanec and Zimmermann (2009) show that under certain conditions, skilled immigration can reduce income inequality in the host country.

Going a step further into a "General Equilibrium" setting, Boeri and Bruecker (2009) analyze the migration impact under imperfect labor markets and more realistic scenaria. The authors find that labor migration from the EU8 into the EU15 from 2004 to 2007 led to substantial gains for the enlarged EU. For example, the aggregate GDP of the integrated area increased by about $0.2 \%$, which is translated to 24 billion Euros or 28,571 Euros per post-enlargement migrant. The authors calibrate the decline in wages to be $0.08-0.09 \%$ and the increase in unemployment to be $0.04-0.06 \%$ in the EU15 in the shortrun. However, in the long-run the authors find no effects of migration on wages and employment. Looking at distributional effects, they find that in the receiving countries high-skilled workers benefit from migration and less-skilled workers lose more proportionally. In the sending countries, high-skilled workers lose more and less-skilled workers gain.

Lastly, both skilled and unskilled migrants have serious effects on public finance. Migration generates fiscal externalities in the destination and the source country. The move from a poorer to a richer country produces an overall fiscal net gain. For example, tax revenues from the richer nation will increase more than transfer payments to the poorer. However, moving from a low income redistribution country to a high income redistribution country produces a negative total fiscal net gain (Bonin et al., 2008). 


\section{Immigration and Emigration Movements in the EU27}

It is a truism that labor migrants respond to economic conditions and changes, thus they choose the destination countries accordingly. However, fears of immigration by the receiving nations and migration restrictions contribute to an uneven distribution of migrants in the labor market and in demographics. From the receiving country side, we observe some interesting migration patterns. Figure 3 illustrates the distribution of EU10 migrants to EU15. They mostly emigrate to Ireland, the UK and Luxembourg. This is understandable because these EU15 countries were open to labor migration from the beginning of the enlargement. Figure 4 shows the distribution of EU2 migrants to EU15. Clearly, Romanians and Bulgarians choose Italy and Spain as their destination. Affinity in language and somewhat in culture, can explain the pattern of Figure 4. In addition, the majority of Romanian and Bulgarian migrants were women who worked by and large as domestics and caregivers.

\section{$<<<$ Figure 3 about here $>>>$ \\ $<<<$ Figure 4 about here $>>>$}

From the sending countries' perspective, emigration patterns in the EU8 and EU2 are shown in Figure 5. Between 2000 and 2007 these countries experienced tremendous amounts of emigration. Emigration was the highest in Romania, where the number of emigrants skyrocketed when the country joined the EU27 in 2009; Bulgaria followed suit. Among the EU12, Lithuania, Poland, Estonia, and Slovakia witnessed high numbers of emigrants who went to EU15. Consistently, over the years 2000, 2003 and 2007, the Czech Republic and Hungary had the lowest number of emigrants going to EU15.

\section{$<<<$ Figure 5 about here $>>>$}

The EU enlargement increased the rate of overall migration flows. However, because of distortions and government interventions (such as transitory arrangements), the immigrant and emigrant distributions among countries were uneven. Data show that the main EU15 destination country was the UK. Table 3 provides a good documentation of the massive migration flows (in percent). Almost 60\% of Poles went to the UK; another $17 \%$ went to Ireland. Interestingly, 55\% of Slovaks also went to the UK, $21 \%$ went to the Czech Republic and 11\% to Ireland. The majority of Latvians (52\%) also went to the UK and 33\% to Ireland. Spain received the bulk of Romanians (57\%) and Bulgarians (56\%); next was Italy. Oddly enough, Germany - a country with stringent transitional arrangements - also received large 
percentages of migrants from the NMS. For example, $11 \%$ of Poles, $15 \%$ of Bulgarians, and $10 \%$ of Latvians went to Germany through closed doors. This Table shows that closed door policies are not effective tools.

\section{$<<<$ Table 3 about here $>>>$}

Reflecting upon future mobility flows in EU, the European Commission's report (2009) stated that new labor waves from the NMS are doubtful for the following reasons: those who wanted to move have already done so, many NMS migrants want to return to their home countries, and the flows to the UK and Ireland appeared to have peaked in 2006. The same report criticizes the countries that imposed transitional arrangements. The EU enlargement experience has shown that restrictions do not stave off the flows of migrants. Instead, they lead to undeclared labor in the receiving countries with dangerous social ramifications. Finally, restrictions only delay labor market adjustments.

\section{EU-Expansion's Impact on Migrants, the Receiving and Sending Countries}

\section{Characteristics of the NMS Migrants and their Labor Market Outcomes}

The most distinctive labor market characteristic after the enlargement was increased labor market participation and higher employment rates compared to pre-enlargement. Self-employment emerged among EU2 migrants easing the transition and adaptation to the receiving country. However, while immigrants from the NMS are often well educated, the majority of them occupy low or medium skill jobs. Almost a quarter of EU8 immigrants have high education and the majority of them have medium education. EU2 immigrants were less educated than EU8 immigrants. The proportion of highly educated migrants from the EU8 was lower for post-enlargement arrivals, but also the share of the lessskilled has declined. In general, EU2 immigrants were less educated than EU8 immigrants.

Skill mismatch has been a common phenomenon in international labor markets and a large part is attributed to the lack of human capital transferability and language proficiency. More recently, there is an overall improvement in skill match. Interestingly, higher educated migrants from the EU8 countries went to the UK that practiced open-door migration from the beginning.

Using Germany as an example of an EU15 country that resisted free labor mobility from EU12, Brenke et al. (2009) conclude the following: Migration took place even though the country had closed borders 
to the EU12. Since the EU enlargement in 2004 the composition of EU8 immigrants has changed. More recent immigrants from EU8 are older, less educated, work in low-paid jobs, earn lower wages and experience higher unemployment compared to their counterparts prior to enlargement or right after enlargement. It appears that recent EU immigrants in Germany compete with low-skilled non-EU immigrants. On the other hand, EU12 immigrants are more likely to be self-employed than native Germans, which is, arguably, one way to overcome labor market discrimination or assimilation difficulties. Among recent EU10 migrants in Germany, 40\% were self-employed. Self-employment is thus a way to circumvent transitional arrangements!

With the exception of Germany, EU8 immigrants in EU15 exhibit higher employment rates and lower unemployment and inactivity rates after enlargement compared to the populations in either the sending or receiving countries. In the UK, post-enlargement EU8 immigrants were more educated. Selfemployment rates were low among recent EU10 immigrants in the UK and high among EU2 immigrants in the UK (50\%). These immigrants were predominantly temporary (self-reported), males (but females in Germany), and of young age.

\section{Labor Market Outcomes for the Receiving Countries}

The main claim surrounding labor migration in conjunction with the EU enlargement has been a negative impact on receiving countries, including a decrease in wages and employment as well as higher dependability on welfare systems. However, there is no evidence to support this claim. Even though there may be some displacement of the natives working in low skilled jobs in some sectors, this has not raised aggregate unemployment, and thus, no indication of negative effects in the recipient countries exists. The 2009 European Commission report refers to the impact of the EU enlargement on public finances and the welfare state as negligible. Nonetheless, migration flows in the receiving countries in the short-run have created excess demand for education, housing and health care.

A more recent study on the impact of unemployment benefits on migration in 19 European countries from 1993 to 2008 shows that (i) there is a small correlation between unemployment benefits and migration for non-EU immigrants only, and (ii) there is no relationship between unemployment benefits and migration flows within the EU for EU migrants (Giulietti et al., 2011). These findings do not support "welfare migration.” 
Following Kahanec and Zimmermann (2009), there was a general increase in migrant inflows from EU10 and EU2 to EU15. In 2003, migrants from EU10 and EU2 were about $0.2 \%$ of the EU15 population. In 2007, migrants from EU10 and EU2 were about 0.5\%. Still, these are very small numbers for a united EU labor market. They are also very small compared to other EU15 nationals migrating in EU15 (1.7\%), or compared to non-EU nationals in EU15 (4.5\%).

Opening up the borders to EU 12 was beneficial to the rest of Europe, for it allowed rapid trade integration, and more positive socioeconomic conditions throughout Europe. On the other hand, studies show that countries that practice migration restrictions and enforce a more closed labor market miss out in the long run. The UK, Ireland, Spain, and Germany are contrasting examples of EU15 countries with different migration policies after enlargement. Below, I present their absorption rate, unemployment and welfare.

The UK: Even after controlling for potential observable and unobservable confounding factors there was no impact on the UK unemployment rate or wages. Perhaps there was some negative effect on the relative wages of the least skilled. It is rather the "fear of unemployment" that has risen in response to immigration from the new member states and that may suppress inflationary pressures. The number of EU8 nationals applying for social benefits is low; child benefits constitute the largest category. Immigrants in the UK generally fill in gaps in labor supply.

Ireland: Similar to the UK there were no negative effects from the EU enlargement in Ireland. There was no "welfare tourism" either. While some displacement of natives took place in some sectors, there was no rise in aggregate unemployment. Indeed, EU12 immigrants in Ireland contributed to job "upgrading" or upward economic mobility of natives.

Spain: The EU enlargement and Spain's open labor markets significantly contributed to increased migration from the NMS. In addition, it gave many migrants from the NMS (already in the country) a legal status. That is, migrants from the NMS have the same job security as any native, and as legal workers these migrants contribute to social security. During the period 2004 to 2007, Spain had a booming economy and desperately need immigrants. Nonetheless, immigrants in Spain exhibit insufficient employment prospects. In fact, after controlling for education and other characteristics, new 
migrants from the NMS are less likely to be employed compared to their native counterparts and other non-EU immigrants, most of whom are Latinos (Kahanec and Zimmermann, 2009).

Germany: EU enlargement fears kept Germany from opening up to the NMS. A case study about Germany in Kahanec and Zimmermann (2009) shows that this closed-door policy produced negative effects. The closed-doors transitional period that the country imposed on itself prevented Germany from attracting high skilled workers. At the same time, Germany attracted more and more low skilled migrants who end up competing with other non-EU immigrant workers for low skilled jobs. Indeed, it is important to note that the demographics of immigration from the EU8 countries to Germany have changed dramatically over the five "transitioning" years. During the transitional arrangements, some self-employed workers from the EU8 were allowed to settle in Germany and run a business. However, they were not allowed to employ workers from their home country. On January 1, 2009 the Beitrag der Arbeitsmigration zur Sicherung der Fachkräftebasis instituted openness to high-skilled workers. Critics say that the generally strong negative signals associated with Germany's policy may nullify the effectiveness of this new contract about skilled workers. Despite these arrangements, the number of migrants from the EU12 countries has clearly increased. The net flow of EU8 migrants became 2.5 times larger than in the four-year period before enlargement. The migration flows in Germany after the EU enlargement consisted mostly of Poles, especially men, and migrants from the EU8, who have exhibited large fluctuations.

$<<<$ Table 4 about here $>>>$

\section{Labor Market Outcomes for the Sending Countries}

In 2003, a year before the effective enlargement, the NMS were facing jobless growth (European Commission, 2009). Unemployment was especially severe in Poland. To ascend to EU as equal partners the NMS had to undergo various structural reforms prior to enlargement. To align the old with the new states and reduce the gap between them when new countries join the EU, they receive large flows of Foreign Direct Investment (FDI), which in turn create jobs and contribute to the economic development of the new member countries. One of the prerequisites of ascension is also that the labor markets of the NMS be competitive and flexible. Eager to fulfill the economic accession criteria, the NMS worked hard to converge toward the Old Member States (OMS) in terms of products, labor and 
financial market regulations (European Commission, 2009). Interestingly, some observers pointed out that 'reform fatigue,' has reduced the efforts of the NMS to really reform their economies (European Commission, 2009).

The NMS were undoubtedly, the biggest winners after the EU enlargement; they experienced improvements in employment opportunities and in overall living standards. D’Auria et al. (2008) find that there were big changes at the EU8 (EU2) level after enlargement. As people left their home countries to work in other EU15 countries, GDP declined in the sending countries. But there were gains in real wages, productivity and GDP per capita. In 2007, unemployment showed a serious decline for all NMS compared to the 2003 levels (European Commission, 2009).

An eternal characteristic of immigrants in the receiving countries is to send remittances to their families and friends back in the home country. Remittances are often a significant part of the national accounts of the home countries that are usually less developed than the host countries. 2006 World Bank data on workers' remittances to the NMS show that remittances were close to 6\% of GDP for Romania and Bulgaria, and more than 3\% in Lithuania. Poland and other Baltic States also received significant amounts of remittances (European Commission, 2009). Overall, up until the economic crisis, the NMS have recorded positive and increasing remittances.

Aggregate data for the NMS document decreasing unemployment, increasing number of vacancies, and employment growth, as well as increasing wages in the post-enlargement period. However, to the extent that the outflow of migrants consists of skilled and employed workers, this can generate shortages which may put a strain on social security. A World Bank (2006) study showed no incidence of massive "brain-drain” from the NMS, although in some sectors (such as health care) the emigration of highly skilled specialists was relatively large. To remain optimistic for the future, brain circulation is expected to go on among member states (European Commission, 2008).

In general, emigration increased between 2000 and 2007 for all EU8 and EU2 countries. Poland and the Baltic States are good examples that capture the momentum of emigration upon enlargement. Emigration rates were the highest in Romania, Bulgaria, Lithuania, Poland, Estonia, and Slovakia. The lowest were in the Czech Republic and Hungary. A special case is Poland, where as emigration increased it also switched from going to Germany to migrating to the UK. The number of Poles who 
stayed abroad for at least two months from early 2004 until early 2007 tripled; from around 180,000 Poles to around 540,000. Kahanec and Zimmermann (2009) present interesting evidence that the EU enlargement incited the emergence of two distinct emigrant groups from the NMS: the highly-skilled from the "core" countries and the low-skilled from the periphery countries.

\section{The Critical Juncture of the Global Economic Crisis and the EU Enlargement}

The optimistic picture of the EU enlargement up to the end of 2007 was crushed when the financial and economic crises of 2008 affected all EU member states. The crisis contributed greatly to the reshaping of European migration routes and the slowing down of labor market flows. In fact, the crisis impelled migrants from the NMS to return to their home countries. The NMS have been affected the most by the crisis in terms of unemployment and remittances. Specifically, there was deterioration in most aggregate variables; migration flows slowed down and many migrants started returning home. The reasons that prompted return migration were job loss, and of course no restrictions on movement in case they would want to go back after the economy would pick up. The economic crisis also intensified the negative feelings towards holding mismatched jobs and exacerbated the temporary intentions to stay abroad. Social pressure fuelled by economic difficulties in the destination countries, and the shrinking of social (ethnic) networks were additional push factors to return.

The global crisis hit both the destination and sending countries; some countries were hit harder than others. Iceland, for example, and other Baltic States were totally vulnerable to the crisis as their banking sector was by international banks. Germany felt the economic crisis through its exports. Spain and Ireland had their own real estate bubbles and Greece was in severe debt before the crisis arrived. The inextricable globalization along with the Eurozone bond made it more difficult to recover. Overall, however, east-west migration is expected to continue after the crisis, albeit at a lower rate. The composition of the migrant flows may change due to the crisis.

\section{Economic Downturn and Flows of Immigrants: the UK}

Current data about labor migration to the UK reveal that the flow of labor migrants to the country has substantially dropped in the aftermath of the 2008 financial and economic downturn. Using National 
Insurance Numbers (NINo), Table 5 shows that in the pre-crisis period of 2007/2008 733,090 migrants went to the UK. The flow dropped to 686,110 migrants in the 2008/2009 period and dramatically dropped again in 2009/2010 to 572,740. In spite of a relative rebound in 2010/2011 to about 704,910, this level is still lower than the flow of migrants to the UK before the crisis.

\section{$<<<$ Table 5 about here $>>>$}

Based on NINos, Figure 6 shows that since the crisis of 2008 the flow of Polish workers to the UK has fallen by almost 50 percentage points. In fact, the flow of migrant workers from all the NMS to the UK has dropped compared to its level in July-September 2008. In contrast, the flow of Romanian migrants to the UK has increased over the same time period. The flow of Latvians and Lithuanians has more than doubled, albeit following sharp ups and downs.

\section{$<<<$ Figure 6 about here $>>>$}

\section{Remittances}

Remittances are the link between labor migration, national accounts and development. They also hold tight the three actors in migration. Remittances constitute a significant part of Bulgaria's and Romania’s GDP and are also important in the Baltic States. In Poland and the Baltic states remittances are mostly of a seasonal nature. They are largely used for household consumption and purchase of durable goods with a recent tendency to invest in human capital and tertiary education (World Bank, 2006). The impact of these remittances on economic development is until now rather limited.

While remittances are quite resilient to shocks, the crisis seems to have affected some remittance flows more than others in the EU. Looking at outflows of immigrants' remittances from the EU27 to EU27 countries, Figure 7 illustrates first an increase from 2004 to 2008. Specifically, remittance flows within the EU27 increased from $€ 6.1$ billion in 2004, to €9.3 billion in 2007. Second, by 2008, remittances fell to $€ 8.9$ billion and kept falling to reach €8.3 billion in 2009. Thus the global financial and economic downturn of 2008 substantially affected intra-EU remittance flows. On the other hand, remittance outflows to outside the EU countries did not fall as much and the fall was not recorded until 2009. This shows a more resilient trend. The dotted line in Figure 7 represents the total outflows of workers' 
remittances from the EU27. In the EU27, total outflows in 2009 dropped to about $€ 30.3$ billion compared to $€ 32.6$ billion in 2008; entailing a 7\% dive.

\section{$<<<$ Figure 7 about here $>>>$}

Furthermore, Table 6 we document the major remittance corridors or inflows from some EU countries to other EU countries in 2007 and in 2008. Remittances from Polish workers in the UK back to Poland amounted to $€ 1,061$ million in 2007. They dropped to €901 million in 2008, or a $-15.1 \%$ drastic decrease within a year. Another negative percentage change of 4.2 was recorded for remittances from France to Portugal. However, remittances from Spain to Romania increased by 22.5\% between 2007 and 2008. Similarly, remittances from Italy to Romania also increased by $9.4 \%$ between 2007 and 2008.

\section{$<<<$ Table 6 about here $>>>$}

\section{Summary and Conclusion}

In this chapter, I offer a summary and an evaluation of the achievements and impact of the 2004 and 2007 EU enlargement to the EU27. Most findings come from the Kahanec and Zimmermann (2009) edited book on post-enlargement. For the idealists and romantics, a European Union of 27 partner/countries with unfettered trade and people mobility was an exhilarating moment. For politicians, it was an opportunity to give nice speeches and touch base with their voters. Fear mongering and additional confusion from the media rendered many citizens of the "old countries" (EU15) apprehensive of their fellow Europeans. Eurobarometer polls show that more than one in two Europeans in the EU27 believed that the EU enlargement contributed to job losses in their own country.

The European countries that have been traditionally more open to labor mobility, immediately opened up their labor markets to the newcomer citizens from the NMS. Others, imposed stringent temporal prohibitions following the "2+3+2" formula. That is, labor markets will be closed for a maximum of 7 years after the EU enlargement for the EU12 citizens.

In this chapter assesses and evaluates the effectiveness of the enforced policies to free mobility, while it identifies winner and losers. It also addresses questions related to the specificities and intricacies of the labor markets, to human capital and labor mobility and to pros and cons from the perspectives of the 
EU15 and EU12. It continues by adding the role of the global economic crisis in the EU enlargement outcomes. We seek to give answers to the following questions: How have the transitory arrangements affected the post-enlargement migration flows? Will many more people decide to leave the NMS for the old ones, or will the numbers stabilize? What will be the timing, duration and frequency of migrants' sojourn abroad? Will the EU27 be able to move forward after the global crisis?

Looking back at this historic natural experiment, we can identify winners and losers and assess the efficacy of the applied policies. In general, migration from the NMS to the old EU15 has increased after the 2004 and 2007 enlargements. For the EU15 countries that opened their labor markets (the UK, IR, ES, IT) there is a "migration diversion" effect; some evidence suggests that migration diversion occurred through migrants' characteristics. “Closed” economies (AT, DE), however, also experienced increased immigration after the enlargement. It appears that the NMS migrants who wanted to go abroad and work had already gone and only registered after the enlargement.

The EU as a whole experienced substantial positive effects in terms of GDP, GDP per capita, productivity and wages following both waves of expansion. It also experienced a somewhat smaller effect for employment in the long run. There is no evidence of negative impacts on the receiving countries' labor markets in terms of wages, employment, or unemployment. Similarly, there is no evidence of negative impacts on the public budgets of the receiving countries or of "welfare tourism." On the other hand, sending countries have experienced some disadvantages due to large outflows of their young and skilled workers, which might have a negative impact on economic growth and demographics in the long-run. However, the often temporary nature of these migration flows implies brain circulation and thus positive effects overall. In the short-run, there are some negative consequences such as limited remittances, labor shortages and vacancies in addition to skill mismatch, and income pressures. These externalities are often offset by decreased unemployment, remittances and free mobility. Thus while some risks exist, the overall outcome is mostly positive for EU members.

With the exception of the recent EU8 immigrants to Germany, immigrants experienced greater labor market participation and higher employment rates than the populations in either the sending or receiving countries. At least until the global economic crisis hit Europe in 2008, EU12 migrants fared well in EU15 countries; they were among the winners. In countries with closed doors, such as Germany, there was a deterioration of migrants skills over time. This is at odds with the country's needs 
of highly skilled immigrant workers. Therefore, by enforcing transitional arrangements Germany has lost. Not only closed doors implied negative selection of immigrants for Germany, but also produced a delay in the adjustment of the labor markets. This was critical for Germany because this adjustment overlapped with the global crisis and intensified any negative impacts. A rescue plan or a loophole to close doors was the self-employment door.

Labor migration is considered to be beneficial for the migrants, the sending and receiving countries. It improves the efficiency, productivity and wellbeing of all societies. International labor migration promotes democracy, international trade and human capital exchange. Labor market intervention in the EU comes in various forms of policies through services, measures and support. Training, employment incentives, direct job creation and retirement are among necessary measures. Some nations invest more than others. As of 2007, Belgium takes the leading role in expenditure on labor market policy with well over 3\% of its GDP. It is unclear what future challenges may present themselves in terms of labor migration and what it will mean to the economies of the sending and receiving countries. There is neither any predictability in the composition and demographics of the migrants, nor evidence if the figures will ever stabilize.

Various labor migration experts advise against any type of restrictive practices on free movement for the benefit of the increased efficiency of human capital allocation, stable and equal migration flows, and brain circulation for the sending and receiving countries. On a transnational level, free migration strengthens EU global competitiveness, sustainability and expands labor market opportunities. The overall movement of labor from the NMS to the OMS was not as large as anticipated. In many EU15 Member States the majority of immigrants are from non-EU countries. Non-EU citizens residing in the EU experience negative effects, especially since the recent financial crisis that increased unemployment rates and worker mismatches among them. These immigrants also experienced stagnant employment growth and lower wages. Interestingly, while remittances from the EU27 to EU27 have decreased in 2008, remittances to non-EU countries have exhibited more resilience.

The global crisis of 2008 affected the EU27 as a whole and also affected some member states more than others. It showed how inextricable linked countries are, and how vulnerable to shocks the labor markets are. The optimistic view of the EU enlargement was quickly effaced by the negative effects of the crisis. As the EU27 and the rest of the world are recovering from the 2008 crisis, new shocks are 
uncovered such as sovereign debt that threaten the Eurozone. Europe 2020 is determined to achieve a high level of employment, produce a unique human capital that will match the digital age, and invest in innovation.

\section{References}

Boeri T. and H. Bruecker (2005). "Why are Europeans so tough on migrants?" Economic Policy, Vol. 20, Issue 44, Pp. 629-703.

Boeri T., H. Bruecker, and A. Hauptmann (2000). "Labor Mobility in the Enlarged EU: Who Wins, Who Loses?" in Kahanec, M. and K. F. Zimmermann, EU Labor Markets After Post-Enlargement Migration. Springer-Verlag, Berlin. Pp. 47-70.

Bonin, H., W. Eichhorst, C. Florman, M. O. Hansen, L. Skiöld, J. Stuhler, K. Tatsiramos, H. Thomasen, and K. F. Zimmermann (2008). "Geographic Mobility in the European Union: Optimising its Economic and Social Benefits." IZA Research Report No. 19, 159 pages.

Brenke, K., M. Yuksel, and K.F. Zimmermann (2009). “EU Enlargement Under Mobility Restrictions: Consequences for Germany,” in M. Kahanec and K. F. Zimmermann (eds) EU Labor Markets After Post-Enlargement Migration. Springer-Verlag, Berlin. Pp. 111-129.

Clemens, M. A. (2011). "Economics and Emigration: Trillion-Dollar Bills on the Sidewalk?" Journal of Economic Perspectives. Vol. 25, No. 3. Pp 83-106.

Constant, A. F., A. Xidous, and B. Tien (2010). IOM report

D’Auria, F., K. McMorrow, and K. Pichelmann (2008). "Economic Impact of Migration Flows Following the 2004 Enlargement Process: A Model Based Analysis." European Economy Economic Papers, No. 349, Brussels, European Commission.

European Commission (2009). Five Years of an Enlarged EU: Economic Achievements and Challenges. European Economy 1|2009. European Communities: Luxembourg.

European Commission (2010). Lisbon Strategy Evaluation Document. Commission Staff Working Document, European Commission, Brussels.

Giulietti, C., M. Guzi, M. Kahanec, and K. F. Zimmermann (2011). "Unemployment Benefits and Immigration: Evidence from the EU." IZA Discussion Paper No. 6075.

Kahanec, M. and K. F. Zimmermann (2009). EU Labor Markets After Post-Enlargement Migration. Springer-Verlag, Berlin.

World Bank (2006). International Migration, Remittances and the Brain Drain. Washington, DC, World Bank. 
Table 1: Current Transitional Arrangements in the EU

\begin{tabular}{ll}
\hline \hline Member State & Workers from Bulgaria and Romania/EU25 \\
\hline Belgium & Restrictions with simplifications \\
Czech Republic & Free access - national law (1 January 2007) \\
Germany & Free access (1 May 2009) \\
Estonia & Restrictions with simplifications* \\
Ireland & Free access (1 January 2007) \\
Greece & Restrictions \\
Spain & Free access (1 January 2009) \\
& Free access (1 January 2009) \\
France & Restrictions for workers from Romania (22 July 2011- safeguard clause) \\
Italy & Restrictions with simplifications \\
Cyprus & Restrictions with simplifications \\
Latvia & Free access (1 January 2007) \\
Lithuania & Free access (1 January 2007) \\
Luxembourg & Free access (1 January 2007) \\
Hungary & Restrictions with simplifications \\
Malta & Free access (1 January 2009) \\
Netherlands & Restrictions \\
Austria & Restrictions with simplifications \\
Poland & Restrictions with simplifications* \\
Portugal & Free access (1 January 2007) \\
Slovenia & Free access (1 January 2009) \\
Slovakia & Free access (1 January 2007) \\
Finland & Free access (1 January 2007) \\
Sweden & Free access (1 January 2007) \\
United Kingdom & Free access (1 January 2007) \\
Bulgaria & Restrictions \\
Romania & No reciprocal measures \\
EU2 & No reciprocal measures \\
\hline \hline
\end{tabular}

Note: * Restrictions also on the posting of workers in certain sectors

Source: European Commission, Employment, Social Affairs and Inclusion (as of 11August 2011) Under: http://ec.europa.eu/social/main.jsp?catId=508\&langId=en 
Table 2: Total Annual Inflow and Net Migration Numbers by Citizenship in Germany

\begin{tabular}{|c|c|c|c|c|c|c|c|}
\hline Citizenship & $\underline{2000}$ & $\underline{2001}$ & $\underline{2002}$ & $\underline{2003}$ & $\underline{2004}$ & $\underline{2005}$ & $\underline{2006}$ \\
\hline & \multicolumn{7}{|c|}{ A. Total Annual Inflows } \\
\hline Poland & 70,431 & 75,012 & 77,405 & 84,693 & 119,551 & 141,314 & 145,761 \\
\hline Hungary & 15,514 & 16,455 & 15,982 & 13,790 & 16,834 & 18,026 & 18,111 \\
\hline Slovakia & 10,413 & 10,985 & 10,889 & 10,006 & 11,053 & 11,395 & 10,933 \\
\hline Czech. Rep. & 10,392 & 10,207 & 9,601 & 7,873 & 8,275 & 7,762 & 7,125 \\
\hline Slovenia & 1,770 & 2,504 & 2,197 & 1,975 & 2,260 & 1,397 & 1,080 \\
\hline Estonia & . & . & . & 738 & 667 & 635 & 529 \\
\hline Latvia & . & . & . & 1,642 & 2,085 & 2,248 & 1,857 \\
\hline Lithuania & . & . & . & 2,775 & 4,150 & 4,859 & 4,477 \\
\hline EU8 & 108,520 & 115,163 & 116,074 & 123,492 & 164,875 & 187,636 & 189,873 \\
\hline Romania & 22,521 & 18,547 & 22,376 & 22,329 & 22,203 & 22,052 & 22,532 \\
\hline Bulgaria & 10,008 & 12,516 & 12,371 & 12,613 & 10,891 & 8,492 & 7,260 \\
\hline Turkey & 39,575 & 44,189 & 47,616 & 41,908 & 36,275 & 30,002 & 26,059 \\
\hline Russia & 25,996 & 28,208 & 29,072 & 25,671 & 23,168 & 19,072 & 14,274 \\
\hline Ukraine & 14,349 & 16,053 & 16,260 & 14,005 & 12,171 & 9,091 & 6,520 \\
\hline Other countries & 153,116 & 175,217 & 174,215 & 150,830 & 136,713 & 125,127 & 121,849 \\
\hline Germany & 132,773 & 134,616 & 128,238 & 118,019 & 131,752 & 92,953 & 77,082 \\
\hline EU15 & 115,359 & 105,896 & 97,127 & 86,745 & 81,643 & 78,175 & 78,535 \\
\hline \multirow[t]{2}{*}{ Total } & 554,073 & 587,168 & 576,224 & 526,206 & 533,310 & 517,783 & 579,048 \\
\hline & \multicolumn{7}{|c|}{ B. Total Annual Net Migration } \\
\hline Poland & 11,841 & 12,836 & 11,461 & 13,003 & 26,600 & 44,951 & 40,569 \\
\hline Hungary & 1,500 & 2,010 & 685 & -770 & 793 & 2,716 & 3,426 \\
\hline Slovakia & 2,000 & 1,548 & 1,462 & 806 & 1,240 & 2,522 & 1,696 \\
\hline Czech. Rep. & 2,070 & 2,154 & 1,113 & 58 & 433 & 1,868 & 1,034 \\
\hline Slovenia & -32 & 255 & 26 & $-5,867$ & 76 & -37 & 1 \\
\hline Estonia & . & . & . & 268 & -38 & 203 & 60 \\
\hline Latvia & . & . & . & 292 & 510 & 891 & 379 \\
\hline Lithuania & . & . & . & 831 & 1,888 & 2,465 & 1,437 \\
\hline EU8 & 17,379 & 18,803 & 14,747 & 8,621 & 31,502 & 55,579 & 48,602 \\
\hline Romania & 6,900 & 1,319 & 5,840 & 3,634 & 2,896 & 2,334 & 1,627 \\
\hline Bulgaria & 3,511 & 4,819 & 4,027 & 2,860 & 1,137 & 2,746 & 226 \\
\hline Turkey & 7,992 & 14,871 & 17,526 & 11,650 & 5,666 & 2,766 & 881 \\
\hline Russia & 15,816 & 17,770 & 17,202 & 14,094 & 11,360 & 8,366 & 4,078 \\
\hline Ukraine & 10,128 & 10,782 & 9,988 & 8,136 & 6,460 & 3,999 & 1,782 \\
\hline Other countries & 53,820 & 76,198 & 71,707 & 43,516 & 20,558 & 21,075 & 16,269 \\
\hline Germany & 47,930 & 49,330 & 37,330 & 19,484 & 13,524 & $-17,796$ & $-41,009$ \\
\hline EU15 & 5,868 & 2,345 & $-8,486$ & $-10,019$ & $-25,507$ & $-4,401$ & $-2,524$ \\
\hline Total & 83,687 & 155,030 & 133,979 & 89,013 & 53,789 & 91,199 & 31,721 \\
\hline
\end{tabular}

Notes: Authors' calculation using Statistisches Bundesamt (Federal Statistical Office) - Population Register. Outflow numbers are inflow minus net migration numbers. "Other countries" include remaining countries, stateless individuals and individuals with unknown nationality.

Source: Brenke et al. (2009), Table 1. 
Table 3: Preferred Destination Countries of Recent Intra-EU Movers (Age Group 15-64)

\section{Citizenship of EU-nationals residing ... by main EU destination country (percentage of overall for four years or less in another EU number of working age nationals residing four years and less in Member State... another EU Member State)}

\begin{tabular}{|l|l|l|l|}
\hline Poland & $59 \%$ to the UK & $17 \%$ to IE & $11 \%$ to DE \\
\hline Romania & $57 \%$ to ES & $26 \%$ to IT & $2 \%$ to the UK \\
\hline Bulgaria & $56 \%$ to ES & $15 \%$ to DE & $16 \%$ to BE \\
\hline Slovakia & $55 \%$ to the UK & $21 \%$ to the CZ & $11 \%$ to IE \\
\hline Latvia & $52 \%$ to the UK & $33 \%$ to IE & $10 \%$ to DE \\
\hline Other EU Citizens & $38 \%$ to the UK & $17 \%$ to DE & $9 \%$ to FR \\
\hline All recent intra EU-movers & $32 \%$ to the UK & $18 \%$ to ES & $10 \%$ to IE \\
\hline Source: Eurostat, EU LFS, Annual Data 2007, European Commission (2009) & \\
\hline
\end{tabular}

Table 4: Labor Market Outcomes by Citizenship for all Immigrant Groups by Arrival Status.

\begin{tabular}{|c|c|c|c|c|c|c|c|c|c|c|}
\hline \multirow[b]{2}{*}{ EU8-Recent imm. } & \multicolumn{2}{|c|}{ Logincome } & \multicolumn{2}{|c|}{ Loghourly-wage } & \multicolumn{2}{|c|}{ Work Hours } & \multicolumn{2}{|c|}{ Employment } & \multicolumn{2}{|c|}{ Self Employment } \\
\hline & -0.277 & $(0.003)$ & -0.245 & $(0.005)$ & -0.745 & $(0.037)$ & -0.231 & $(0.008)$ & 0.157 & $(0.005)$ \\
\hline EU8-Earlier imm. & -0.210 & $(0.001)$ & -0.166 & $(0.001)$ & -1.199 & $(0.014)$ & -0.127 & $(0.007)$ & -0.009 & $(0.001)$ \\
\hline Non-EU Earlier imm. & -0.126 & $(0.007)$ & -0.104 & $(0.006)$ & -0.741 & $(0.041)$ & -0.125 & $(0.002)$ & -0.021 & $(0.001)$ \\
\hline Non-EU Recent imm. & -0.371 & $(0.003)$ & -0.256 & $(0.005)$ & -2.595 & $(0.076)$ & -0.442 & $(0.012)$ & -0.037 & $(0.002)$ \\
\hline EU15-Earlier imm. & -0.031 & $(0.004)$ & -0.045 & $(0.002)$ & 0.794 & (0.033) & -0.023 & $(0.001)$ & 0.025 & $(0.001)$ \\
\hline EU15-Recent imm. & 0.058 & $(0.009)$ & 0.114 & $(0.004)$ & -1.627 & $(0.138)$ & -0.220 & $(0.008)$ & -0.010 & $(0.002)$ \\
\hline Native-Other & -0.099 & $(0.003)$ & -0.085 & (0.003) & -0.630 & $(0.024)$ & -0.061 & (0.003) & -0.021 & $(0.000)$ \\
\hline Gender & -0.469 & $(0.009)$ & -0.179 & $(0.007)$ & -8.597 & $(0.050)$ & -0.129 & $(0.006)$ & -0.041 & $(0.000)$ \\
\hline Age & 0.263 & $(0.014)$ & 0.144 & $(0.024)$ & 2.019 & $(0.373)$ & 0.003 & $(0.024)$ & 0.059 & $(0.002)$ \\
\hline Years of Education & 0.081 & $(0.006)$ & 0.066 & $(0.005)$ & 0.492 & $(0.032)$ & 0.029 & $(0.002)$ & 0.009 & $(0.000)$ \\
\hline
\end{tabular}

Notes: Number of observations are 240,413 for first three regression and 421,840 for last two regressions. Standard errors clustered by state are shown in parantheses. Each regression also controls for polynomial of age up to degree four, and 16 state indicators. "EU8-Recent imm.", "EU15-Recent imm.", " Non-EU Recent imm." show immigrants who arrived after 2004 from EU8 countries, from EU15 countries, and outside the EU respectively. "EU8-Earlier imm.", "EU15-Earlier imm.", " Non-EU Earlier imm." shows immigrants who arrived before 2004 from EU8 countries, from EU15 countries, and outside the EU, respectively. "Native-Other" indicates German citizens who obtained German nationality after birth. The omitted group is German natives in all regressions.

Source: Brenke et al. (2009), Table 4. 
Table 5: NINo ${ }^{*}$ registrations to adult overseas nationals entering the UK, by Year of Registration and world area, in Thousands

\begin{tabular}{lcccc}
\hline \hline & & & & \\
\cline { 2 - 5 } & $\mathbf{2 0 0 7 / 0 8}$ & $\mathbf{2 0 0 8 / 0 9}$ & $\mathbf{2 0 0 9 / 1 0}$ & $\mathbf{2 0 1 0} / \mathbf{1 1}$ \\
\hline All & $\mathbf{7 3 3 . 0 9}$ & $\mathbf{6 8 6 . 1 1}$ & $\mathbf{5 7 2 . 7 4}$ & $\mathbf{7 0 4 . 9 1}$ \\
& & & & \\
Europe - EU excluding Accession Countries & 107.47 & 120.14 & 91.36 & 134.96 \\
Europe - EU Accession Countries & 332.44 & 257.04 & 182.77 & 224.76 \\
Europe - non-EU & 17.21 & 16.10 & 12.90 & 16.64 \\
Africa & 59.63 & 63.31 & 48.14 & 59.72 \\
Asia and Middle East & 149.87 & 163.04 & 190.57 & 213.53 \\
The Americas & 32.64 & 36.45 & 28.15 & 32.78 \\
Australasia and Oceania & 33.35 & 29.53 & 18.34 & 21.59 \\
Others and Unknown & 0.49 & 0.50 & 0.52 & 0.92 \\
\hline \hline
\end{tabular}

Note: ${ }^{*}$ NINo stands for National Insurance Number

Source: UK Department for Work and Pensions, August 2011; Own Presentation

Table 6: Major Remittance Corridors - Inflows, $€$ million*

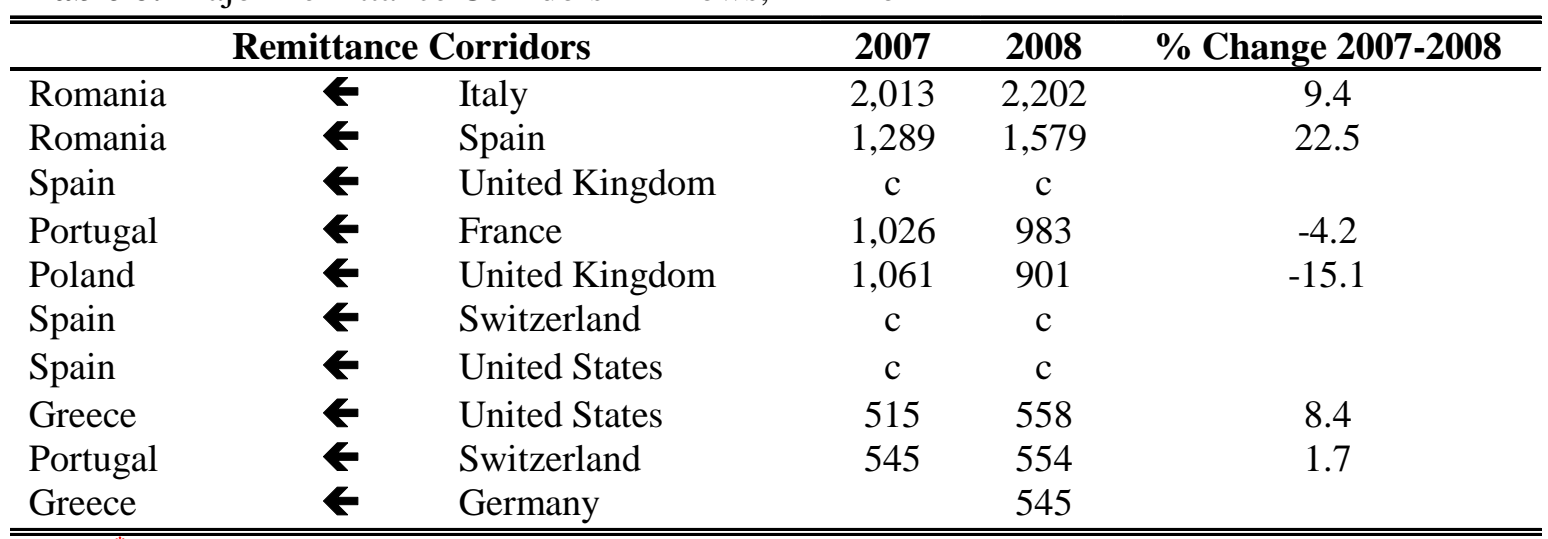

Note: ${ }^{*}$ In order of officially recorded flows in 2008; (c) = confidential

Source: Adapted from Eurostat [bop_remit], Statistics in Focus 40/2010 
Figure 1: EU Enlargement Has Contributed to Job Losses in our Country, by Country

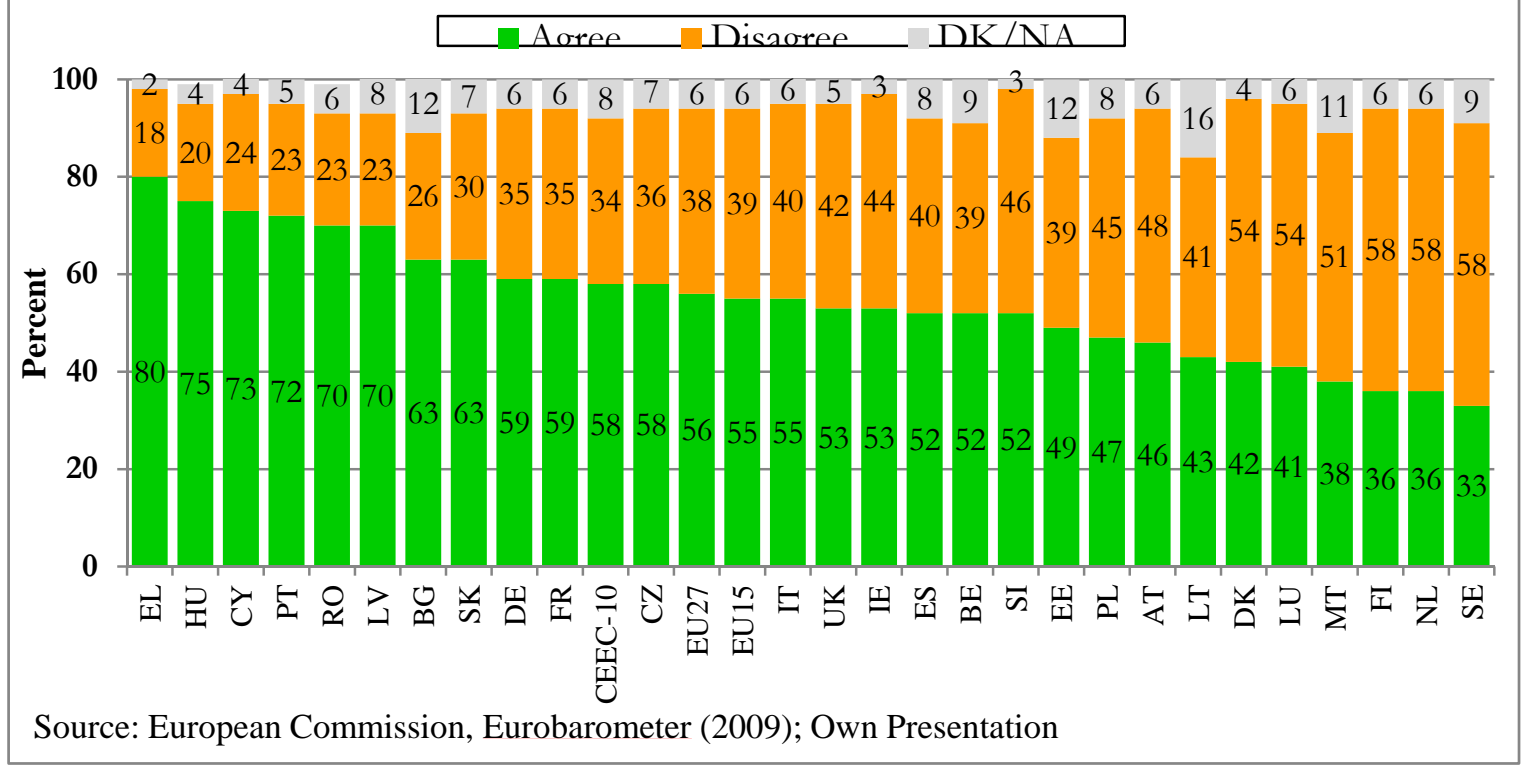

Figure 2: EU Enlargement Has Contributed to Job Losses in our Country, by Segment

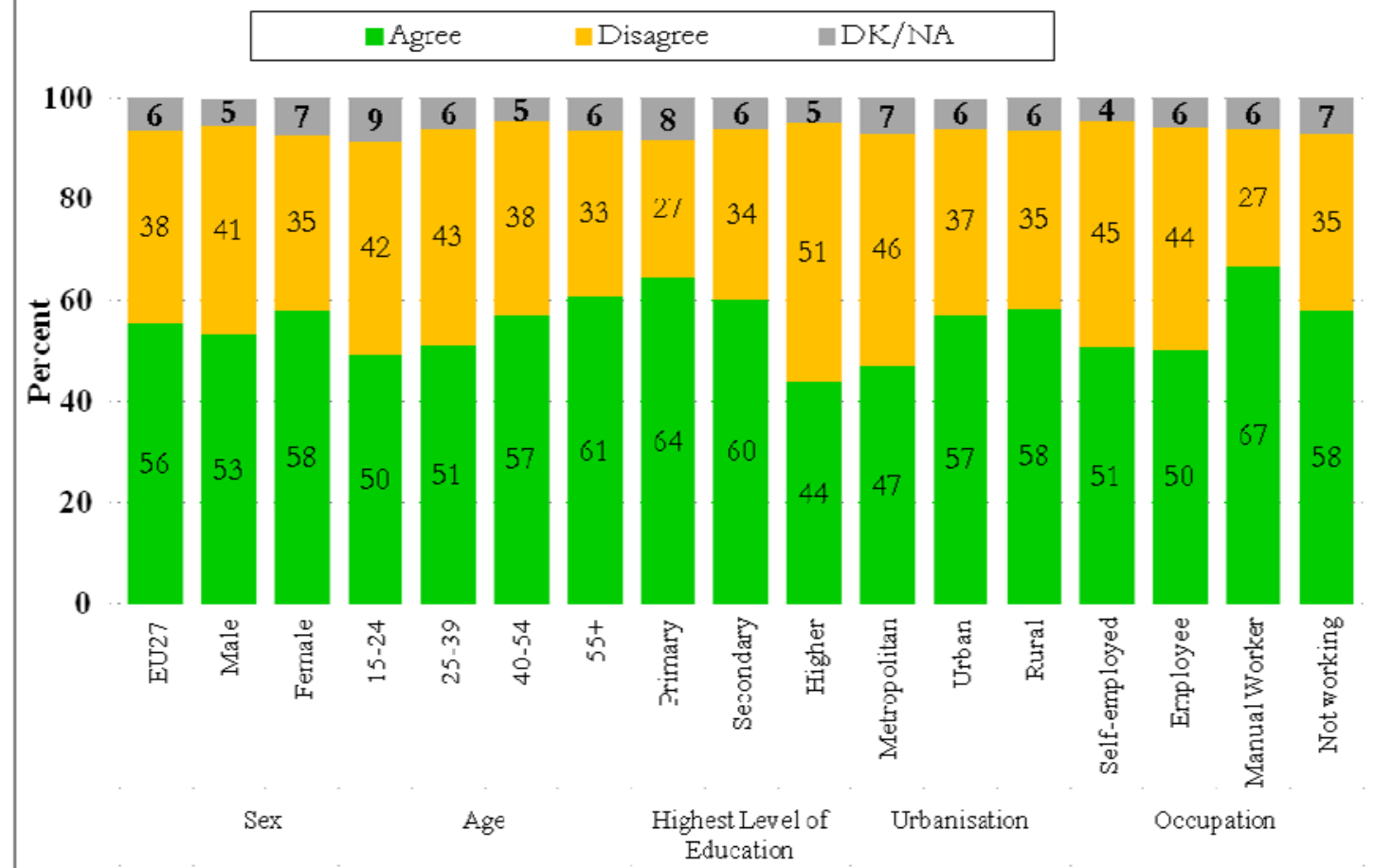

European Commission, Eurobarometer (2009); Own Presentation 
Figure 3: Distribution of EU8 Nationals in EU15

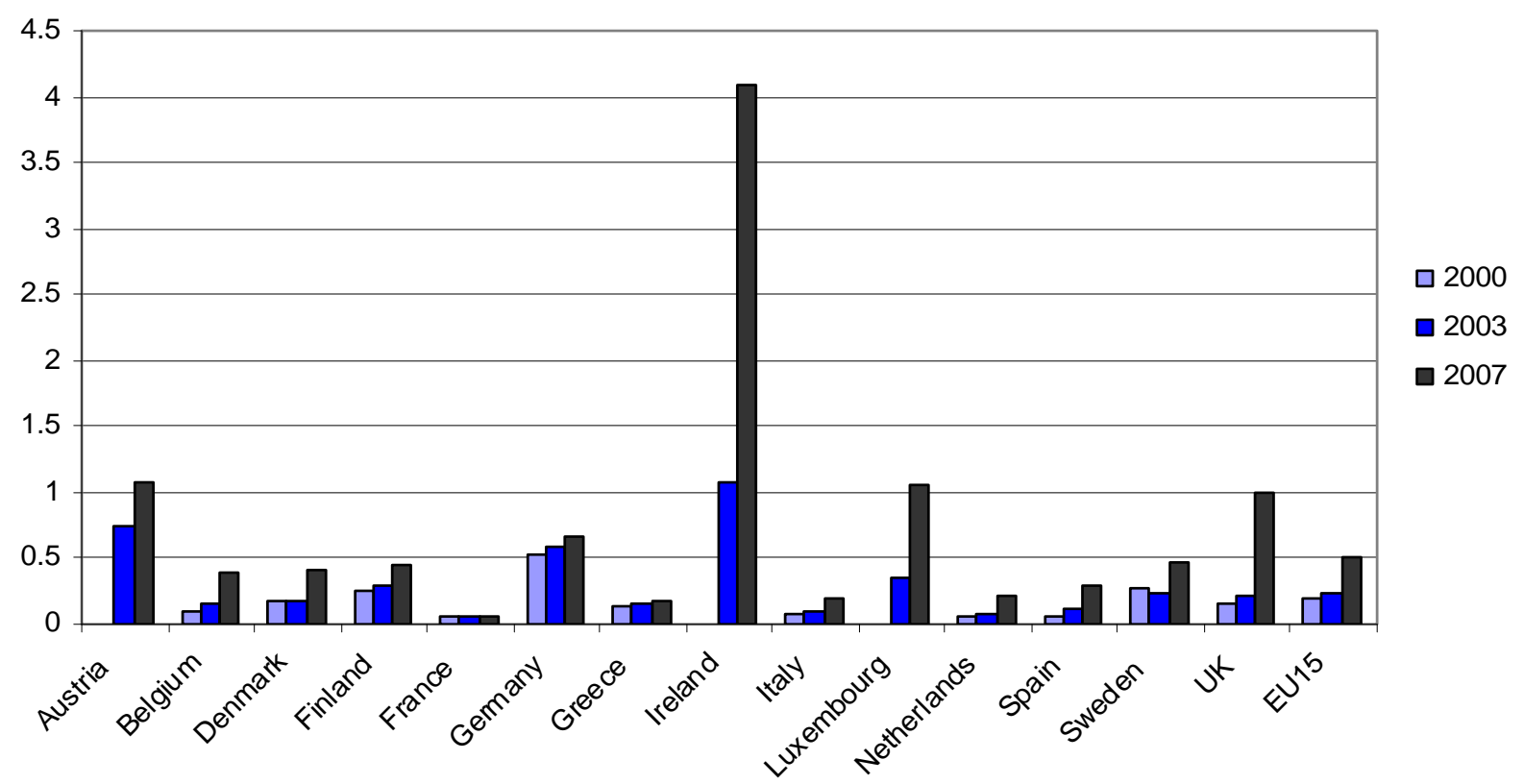

Source: Kahanec et al. (2009), Figure 2.

Figure 4: The Distribution of EU2 Nationals in EU15

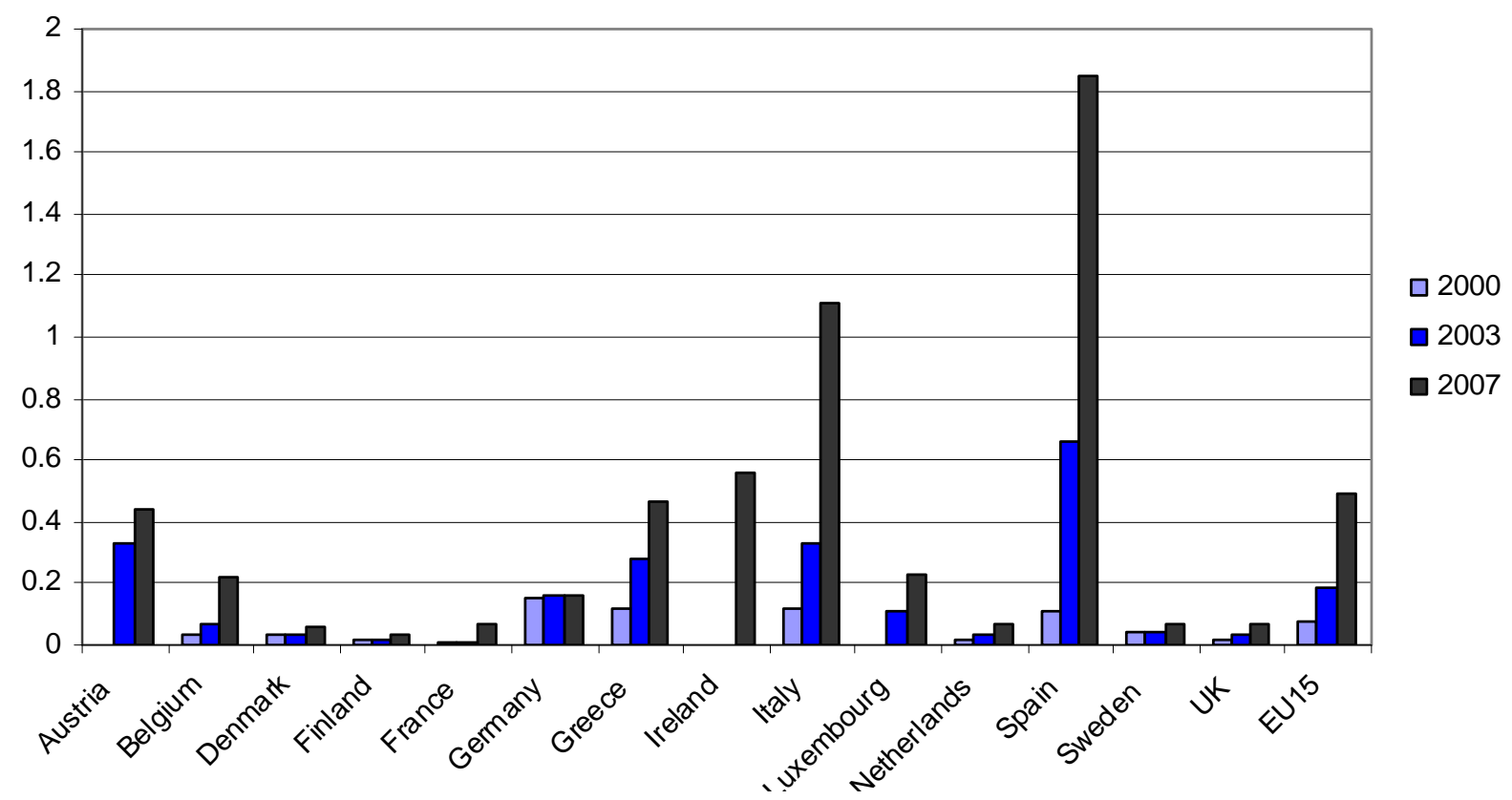

Source: Kahanec et al. (2009), Figure 2 (cont’d). 
Figure 5: New Member States Sending Migrants to EU15

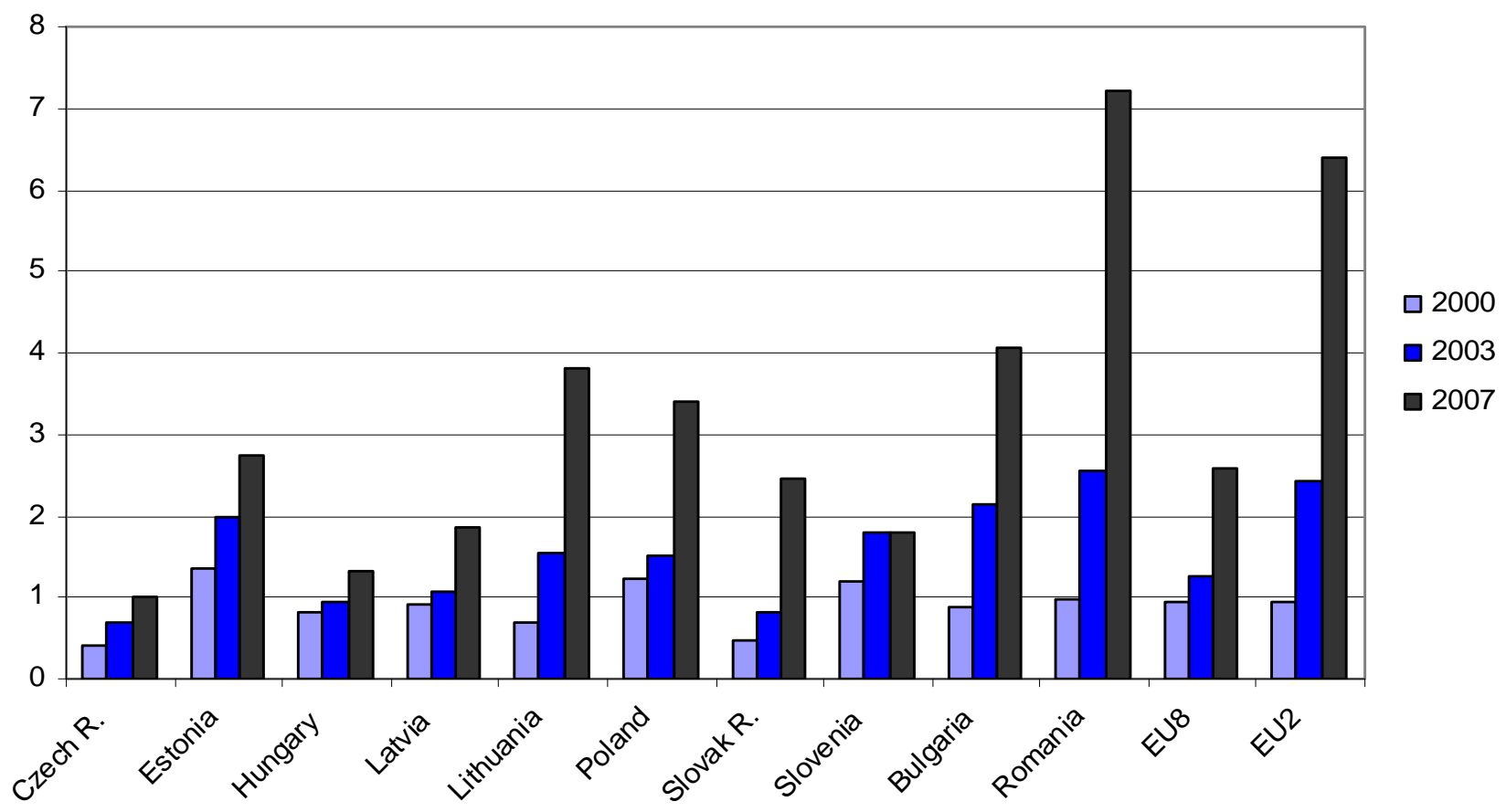

Source: Kahanec et al. (2009), Figure 6.

Figure 6: NINo Registrations to Adult Overseas National Entering the UK from Selected NMS, Index (Jul 0\$-\$ept $0 \$=100)$

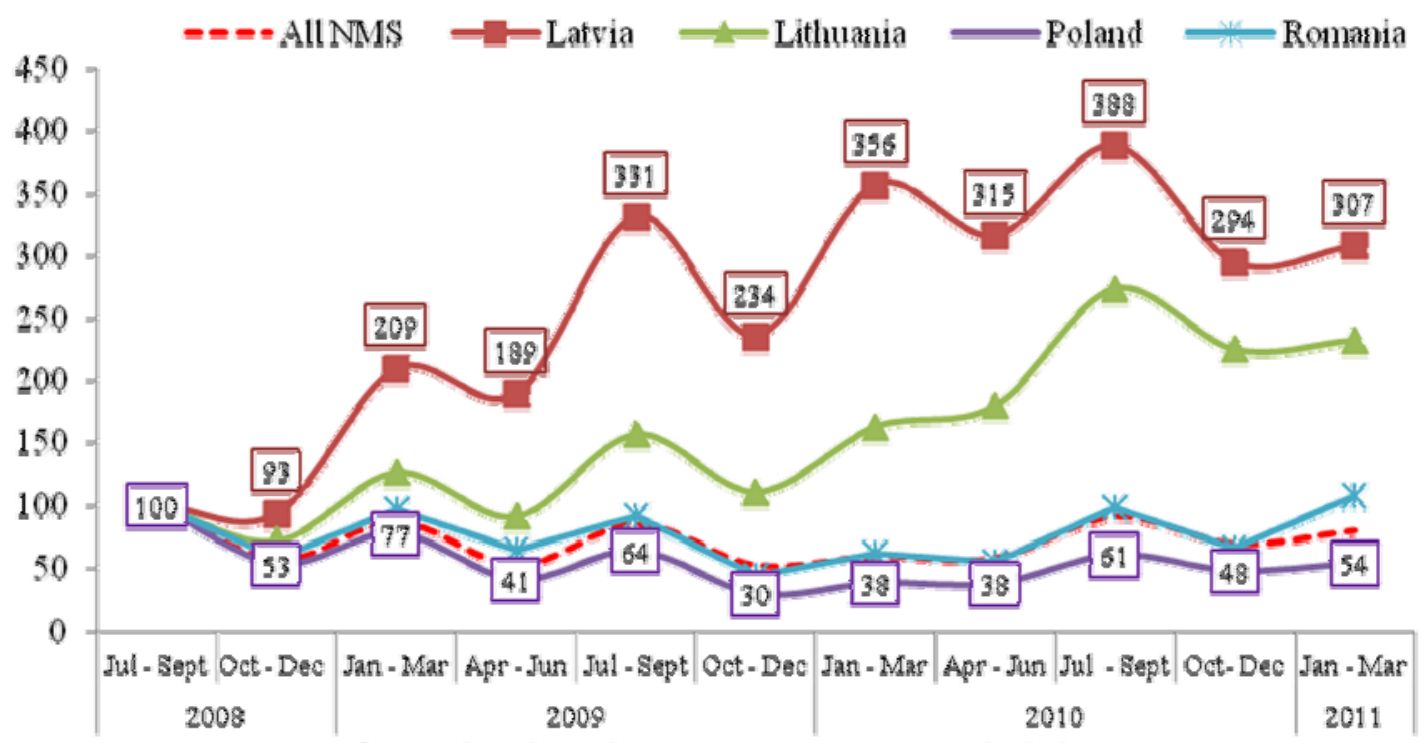

Source: UK Department for Work and Pensions, August 2011; Own Calculation 
Figure 7: Total Outflows of Workers' Remittances from EU27 Member States, € billion

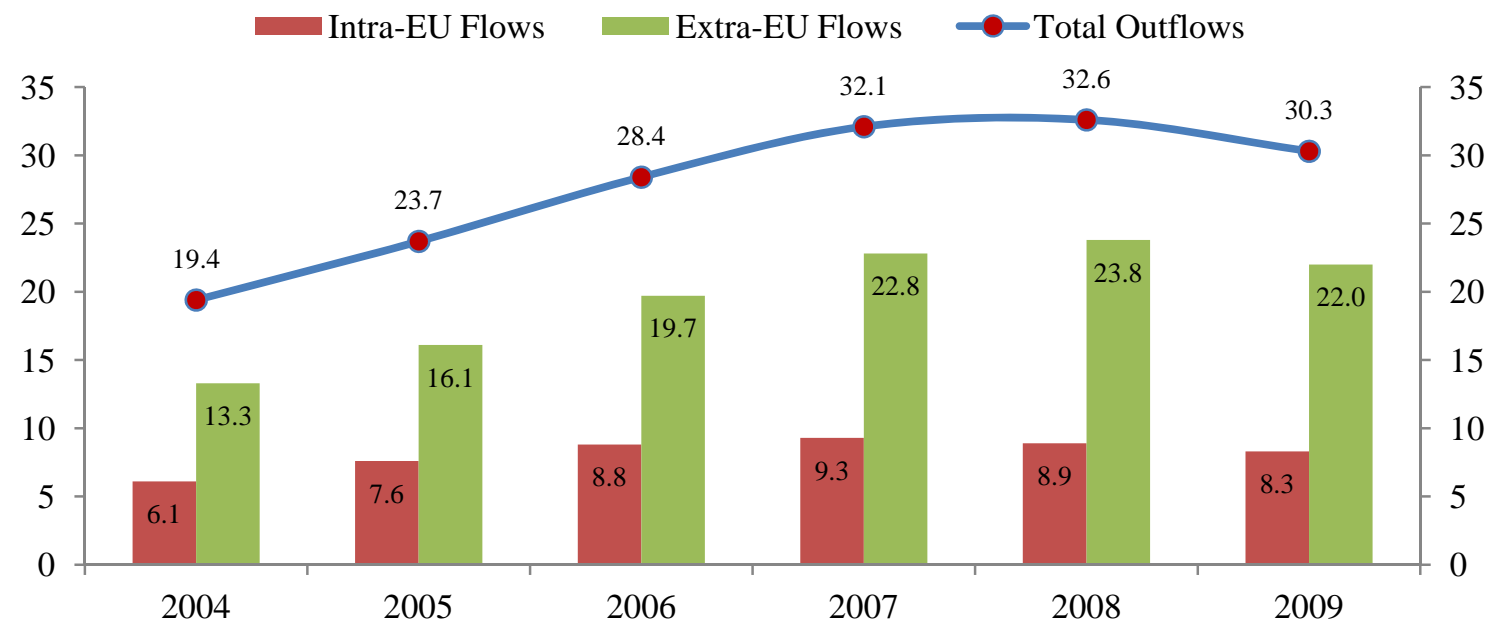

Source: EurostatNewsrelease 191/2010; Own Presentation 